\author{
V.V. Kukharchuk ${ }^{1}$, V.Y. Kucheruk ${ }^{1}$, S.Sh. Katsyv ${ }^{1}$, \\ V.F. Hraniak ${ }^{1}$, D.Zh. Karabekova ${ }^{2}$, A.K. Khassenov ${ }^{2}$ \\ ${ }^{1}$ Vinnitsa National Technical University, Ukraine; \\ ${ }^{2}$ Ye.A. Buketov Karaganda State University, Kazakhstan \\ (E-mail: titanxp2000@ukr.net)
}

\title{
Conditions for «deterministic chaos» phenomenon occurrence in a non-linear rl-diode electric circuit of sinusoid current
}

\begin{abstract}
In this work, the phenomenon of «deterministic chaos» in a nonlinear RL-diode electrical circuit of a sinusoidal current was investigated. The diode is represented by an equivalent circuit, which in the general case includes a nonlinear resistor and two nonlinear capacitances - barrier and diffusion. With certain ratios of the frequency of the current and the parameters of the circuit, the transition process for the period of oscillation of the input voltage hasn't time to finish. In this case, at the beginning of each period there is a residual voltage on the capacitances, that is, each new cycle of the transition process has non-zero initial conditions. It is noted that the residual voltage in each period is different; therefore, the current in the circuit in each period is also different. Thus, in this case, a continuous transition occurs, the parameters of which are chaotic. The simulation of the phenomenon of «deterministic chaos» was carried out in the environment of the MicroCap circuit simulation program. During the simulation for each type of diode, the set of circuit parameters f, R, L (frequency, load resistance, inductance) was divided into two subsets - a subset for which the transition process during the oscillation period of the input voltage has time to finish (the residual voltage on the capacitance is almost zero) and the mode of operation of the circuit can be considered deterministic, and a subset for which the transient process during the oscillation period of the input voltage doesn't attenuate (the residual voltage on the capacitance is significantly different from zero) and the mode of operation of the circuit can be considered chaotic. As a result, the recommended sets of parameters of the circuit for designing the generators of chaotic oscillations were determined.
\end{abstract}

Key words: deterministic chaos, barrier capacitance, diffusion capacitance, residual stress, initial conditions, oscillation generator.

\section{Introduction}

When creating parametric resistive transducers that would allow for required metrological characteristics (particularly, resolution), one should quite frequently transform extremely insignificant changes in output resistance, for instance, during tensiometric measurements.

This in turn results in random interferences' amplification at a desired signal, as a consequence of which a random measurement error grows $[1,2]$. That is why raising the sensitivity of resistive transducers while ensuring a low level of random noises comprises a crucial task.

One of the methods to solve this task consists in the use of $R L$-diode generators of chaotic oscillations [3-6].

The paper [7] presented the analysis of the reasons for chaotic oscillations in $R L$-diode circuits with required calculations carried out.

The objective of this paper is to devise the algorithm for determination of circuit parameters in order to devise the generators of chaotic oscillations.

\section{Results of previous studies}

It was noted above that detailed analysis of the reasons for chaotic oscillations' emergence in $R L$-diode circuits was carried out in paper [7]. In this sub-section, we are only setting forth the basic concepts of this analysis.

The simplest diagram chaotic oscillations' generator is presented by a quadrupole, at the output of which a resistor is switched on (Fig. 1). 


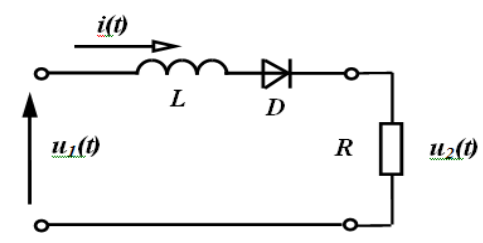

Figure 1. The simplest diagram of chaotic oscillations' generator

According to [8], the diode equivalent circuit in a small signal mode (in the most common case) is shown in Figure 2.

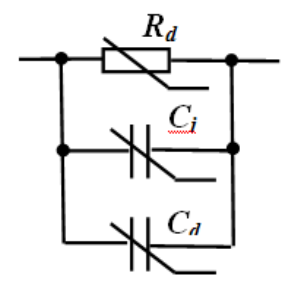

Figure 2. Diode equivalent circuit in a small signal mode

According to this circuit, a diode represents a parallel connection between non-linear resistor $R_{d}$ and two non-linear capacities - a barrier $C_{j}$ and a diffusion $C_{d}$ one.

The barrier capacity is determined using the formula:

$$
C_{j}=\frac{C_{j 0}}{\left(1-\frac{U}{U_{D}}\right)^{n}},
$$

where $C_{j 0}$ - barrier capacity at the diode's zero voltage; $U$ - the diode's current voltage; $U_{D}$ - the diode's diffusion voltage; $n$ - the technological coefficient ranging within $\left(\frac{1}{3} \ldots \frac{2}{3}\right)$.

The diffusion capacity is determined as:

$$
C_{d}=\frac{\tau_{B} I_{S}}{m U_{T}} e^{\frac{U}{m U_{T}}},
$$

where $I_{S}-$ the diode's thermal current; $\tau_{B}-$ the lifetime of minority charge carriers; $U$ - the diode's current voltage; $U_{T}$ - the diode's thermal stress; $m$ - emission factor.

Please note that in the direct voltage mode, given that $U \geq U_{D}$ the barrier capacity may be disregarded. In the back voltage mode, the diffusion capacity may be disregarded.

The equivalent circuit of the simplest generator of chaotic oscillations is shown in Figure 3.

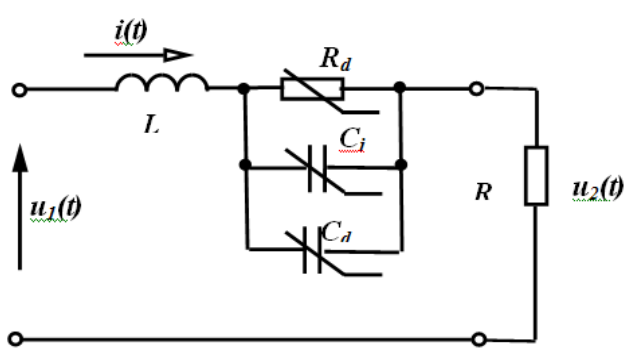

Figure 3. Equivalent circuit of chaotic oscillations' generator

This circuit contains three non-linear elements at once: resistor $R_{d}$, barrier capacity $C_{j}$ and diffusion capacity $C_{d}$. Please note that both resistor resistance and capacities depend on the diode voltage. 
It's as if the current flowing through resistor $R_{d}$ is $i_{1}(t)$, the one flowing along capacity $C_{j}$ being $i_{2}(t)$, and the one flowing along capacity $C_{d}$ is $i_{3}(t)$. Since the voltage at the capacities and at resistor $R_{d}$ is the same, we designate it as $u_{C}(t)$.

Let us compose an equation system under Kirchhoff's laws for the equivalent circuit (Fig. 3).

$$
\begin{aligned}
& i(t)=i_{1}(t)+i_{2}(t)+i_{3}(t) \\
& L \frac{d i(t)}{d t}+R i(t)+R_{d}\left(u_{C}(t)\right) i_{1}(t)=u_{1}(t) \\
& R_{d}\left(u_{C}(t)\right) i_{1}(t)=u_{C}(t) \\
& i_{2}(t)=C_{j}\left(u_{C}(t)\right) \frac{d u_{C}(t)}{d t} \\
& i_{3}(t)=C_{d}\left(u_{C}(t)\right) \frac{d u_{C}(t)}{d t}
\end{aligned}
$$

Since $i_{1}(t)=\frac{u_{C}(t)}{R_{d}\left(u_{C}(t)\right)}$ and $i(t)=\frac{u_{C}(t)}{R_{d}\left(u_{C}(t)\right)}+C_{j}\left(u_{C}(t)\right) \frac{d u_{C}(t)}{d t}+C_{d}\left(u_{C}(t)\right) \frac{d u_{C}(t)}{d t}$, the series of algebraic transformations may be followed by the record:

$$
\begin{gathered}
\left(L C_{j}\left(u_{C}(t)\right)+L C_{d}\left(u_{C}(t)\right)\right) \frac{d^{2} u_{C}(t)}{d t^{2}}+ \\
+\left(\frac{L}{R_{d}\left(u_{C}(t)\right)}+R C_{j}\left(u_{C}(t)\right)+R C_{d}\left(u_{C}(t)\right)\right) \frac{d u_{C}(t)}{d t}+ \\
+\left(\frac{R}{R_{d}\left(u_{C}(t)\right)}+1\right) u_{C}(t)=u_{1}(t) .
\end{gathered}
$$

The resultant expression for non-linear second-order differential equation, to which the circuit operation mode corresponds (Fig. 3), with due account for expressions (1) and (2), looks as follows

$$
\begin{aligned}
& \left(L \frac{C_{j 0}}{\left(1-\frac{u_{C}(t)}{U_{D}}\right)^{n}}+L \frac{\tau_{B} I_{S}}{m U_{T}} e^{\frac{u_{C}(t)}{m U_{T}}}\right) \frac{d^{2} u_{C}(t)}{d t^{2}}+ \\
& +\left(\frac{L}{R_{d}\left(u_{C}(t)\right)}+R \frac{C_{j 0}}{\left(1-\frac{u_{C}(t)}{U_{D}}\right)^{n}}+R \frac{\tau_{B} I_{S}}{m U_{T}} e^{\frac{u_{C}(t)}{m U_{T}}}\right) \frac{d u_{C}(t)}{d t}+ \\
& +\left(\frac{R}{R_{d}\left(u_{C}(t)\right)}+1\right) u_{C}(t)=u_{1}(t) .
\end{aligned}
$$

Let us solve this differential equation using the operator method in general terms.

The operator equation of Kirchhoff's law II for this circuit looks as follows:

$$
I(s)\left(R+s L+\frac{R_{d}\left(u_{C}\right) \frac{1}{s C_{j}\left(u_{C}\right)} \frac{1}{s C_{d}\left(u_{C}\right)}}{R_{d}\left(u_{C}\right) \frac{1}{s C_{j}\left(u_{C}\right)}+R_{d}\left(u_{C}\right) \frac{1}{s C_{d}\left(u_{C}\right)}+\frac{1}{s C_{j}\left(u_{C}\right)} \frac{1}{s C_{d}\left(u_{C}\right)}}\right)=E(s) .
$$


Then the operator presentation of circuit voltage is defined as follows:

$$
I(s)=\frac{E(s)}{\left(R+s L+\frac{R_{d}\left(u_{C}\right) \frac{1}{s C_{j}\left(u_{C}\right)} \frac{1}{s C_{d}\left(u_{C}\right)}}{R_{d}\left(u_{C}\right) \frac{1}{s C_{j}\left(u_{C}\right)}+R_{d}\left(u_{C}\right) \frac{1}{s C_{d}\left(u_{C}\right)}+\frac{1}{s C_{j}\left(u_{C}\right)} \frac{1}{s C_{d}\left(u_{C}\right)}}\right.} .
$$

It is evident that, as a consequence of a considerable non-linearity of this expression, it is impossible to obtain the original of circuit current $i(t)$ in general terms.

Considering the fact that diode parameters do significantly differ from direct and inverse voltage, it would be advisable to analyze the circuit mode using a modified method of lump-linear approximation using transient characteristics and Duhamel's integral.

Iteration algorithm of calculation may be formulated as follows:

1. Let us divide the curve of input sinusoid voltage into equal time intervals, and match each of them with particular sections of BAX diode (i.e. $R_{d}\left(u_{C}\right)$ and particular values $C_{j}\left(u_{C}\right)$ and $C_{d}\left(u_{C}\right)$.

2. For each linearized section of BAX and $C_{j}\left(u_{C}\right)$ and $C_{d}\left(u_{C}\right)$ values, the operator presentation of the circuit's transient characteristics in relation to its current is defined as follows:

$$
\begin{aligned}
& h_{i}(s)=\frac{1}{s\left(R+s L+\frac{R_{d}\left(u_{C}\right) \frac{1}{s C_{j}\left(u_{C}\right)} \frac{1}{s C_{d}\left(u_{C}\right)}}{R_{d}\left(u_{C}\right) \frac{1}{s C_{j}\left(u_{C}\right)}+R_{d}\left(u_{C}\right) \frac{1}{s C_{d}\left(u_{C}\right)}+\frac{1}{s C_{j}\left(u_{C}\right)} \frac{1}{s C_{d}\left(u_{C}\right)}}\right)}= \\
& =\frac{s R_{d}\left(u_{C}\right) C_{d}\left(u_{C}\right)+s R_{d}\left(u_{C}\right) C_{j}\left(u_{C}\right)+1}{s\left(s R_{d}\left(u_{C}\right) C_{d}\left(u_{C}\right) R+s R_{d}\left(u_{C}\right) C_{j}\left(u_{C}\right) R+R+s^{2} L R_{d}\left(u_{C}\right) C_{d}\left(u_{C}\right)+s^{2} L R_{d}\left(u_{C}\right) C_{j}\left(u_{C}\right)+s L+R_{d}\left(u_{C}\right)\right)} .
\end{aligned}
$$

3. Let us find out the original of transient characteristic $h_{i}(t)$ using the decomposition theorem, for which purpose the denominator's root should be determined in the first place:

$$
s\left[s^{2}\left(L R_{d}\left(u_{C}\right) C_{d}\left(u_{C}\right)+L R_{d}\left(u_{C}\right) C_{j}\left(u_{C}\right)\right)+s\left(R_{d}\left(u_{C}\right) C_{d}\left(u_{C}\right) R+R_{d}\left(u_{C}\right) C_{j}\left(u_{C}\right) R+L\right)+R+R_{d}\left(u_{C}\right)\right]=0 .
$$

Equation (9) has three roots:

$$
s_{1}=0, s_{2,3}=\frac{-b \pm \sqrt{b^{2}-4 a c}}{2 a},
$$

where $-a=\left(L R_{d}\left(u_{C}\right) C_{d}\left(u_{C}\right)+L R_{d}\left(u_{C}\right) C_{j}\left(u_{C}\right)\right), b=\left(R_{d}\left(u_{C}\right) C_{d}\left(u_{C}\right) R+R_{d}\left(u_{C}\right) C_{j}\left(u_{C}\right) R+L\right), c=R+R_{d}\left(u_{C}\right)$.

Denominator derivative:

$$
\begin{aligned}
& {\left[s^{3}\left(L R_{d}\left(u_{C}\right) C_{d}\left(u_{C}\right)+L R_{d}\left(u_{C}\right) C_{j}\left(u_{C}\right)\right)+s^{2}\left(R_{d}\left(u_{C}\right) C_{d}\left(u_{C}\right) R+R_{d}\left(u_{C}\right) C_{j}\left(u_{C}\right) R+L\right)+s\left(R+R_{d}\left(u_{C}\right)\right)\right]^{\prime}=} \\
& 3 s^{2}\left(L R_{d}\left(u_{C}\right) C_{d}\left(u_{C}\right)+L R_{d}\left(u_{C}\right) C_{j}\left(u_{C}\right)\right)+2 s\left(R_{d}\left(u_{C}\right) C_{d}\left(u_{C}\right) R+R_{d}\left(u_{C}\right) C_{j}\left(u_{C}\right) R+L\right)+\left(R+R_{d}\left(u_{C}\right)\right) .
\end{aligned}
$$

Therefore, the original of the transient characteristic:

$$
\begin{aligned}
& h_{i}(t)=\frac{1}{R+R_{d}\left(u_{C}\right)}+ \\
& +\frac{s_{2} R_{d}\left(u_{C}\right) C_{d}\left(u_{C}\right)+s_{2} R_{d}\left(u_{C}\right) C_{j}\left(u_{C}\right)+1}{3 s_{2}^{2}\left(L R_{d}\left(u_{C}\right) C_{d}\left(u_{C}\right)+L R_{d}\left(u_{C}\right) C_{j}\left(u_{C}\right)\right)+2 s_{2}\left(R_{d}\left(u_{C}\right) C_{d}\left(u_{C}\right) R+R_{d}\left(u_{C}\right) C_{j}\left(u_{C}\right) R+L\right)+\left(R+R_{d}\left(u_{C}\right)\right)} e^{s_{2} t}+ \\
& \frac{s_{3} R_{d}\left(u_{C}\right) C_{d}\left(u_{C}\right)+s_{3} R_{d}\left(u_{C}\right) C_{j}\left(u_{C}\right)+1}{3 s_{3}^{2}\left(L R_{d}\left(u_{C}\right) C_{d}\left(u_{C}\right)+L R_{d}\left(u_{C}\right) C_{j}\left(u_{C}\right)\right)+2 s_{3}\left(R_{d}\left(u_{C}\right) C_{d}\left(u_{C}\right) R+R_{d}\left(u_{C}\right) C_{j}\left(u_{C}\right) R+L\right)+\left(R+R_{d}\left(u_{C}\right)\right)} e^{s_{3} t} .
\end{aligned}
$$

4. Let us find out the value of current at the end of each time interval with the aid of Duhamel's integral using the formula: 


$$
i\left(t_{k}\right)=i\left(t_{k-1}\right)+\int_{t_{k-1}}^{t_{k}} \frac{d e(\tau)}{d \tau} h_{k}(t-\tau) d \tau .
$$

5. Let us determine the diode voltage using the approximation formula:

$$
u_{d k}=u\left(t_{k-1}\right)-\left(L \frac{i\left(t_{k}\right)-i\left(t_{k-1}\right)}{t_{k}-t_{k-1}}+i\left(t_{k}\right) R\right),
$$

after which $R_{d}\left(u_{C}\right), C_{d}\left(u_{C}\right), C_{j}\left(u_{C}\right)$ parameters should be updated.

6. Let us go back to the algorithm's station 2 and repeat the calculation until $u_{d k}$ value has almost no difference from the previous iteration.

Based on the above algorithm, paper [7] presented a cycle of numeric calculations in MathCAD environment. These calculations proved that, under particular correlations of frequency and circuit parameters, the period of input voltage fluctuations will not be enough for the transient process to come to its end, that is why residual voltage is available at capacities in the beginning of each period, meaning that each new cycle of transient process has non-zero initial conditions. Such being the case, an undamped transient process takes place, with the parameters of this process being of chaotic nature.

It has also been established that transition from a deterministic process to a chaotic one takes place gradually rather than in a leap, meaning that, with the input voltage frequency growth, the residual voltage at capacities will increase quite slowly.

Hence, the triggering event for a chaotic transient process may be formulated as follows:

- in the beginning of each (except for the first one) oscillation cycle, non-zero voltage is present at capacities;

- in the beginning of any two different oscillation cycles, capacity voltages differ from one another.

At the same time, numeric calculations (even in MathCAD environment) are quite a labor-consuming procedure.

Since this paper's objective is determination of the circuit's total recommended parameters for designing of chaotic oscillations' generators, which requires a large volume of calculations, a much quicker simulation of «deterministic chaos» was carried out in the circuit (Fig. 3) using MicroCap general-circuit simulation software.

\section{Results of «deterministic chaos» simulation in a non-linear rl-diode electric circuit of sinusoid current}

Such presentation of circuit model (Fig. 3) is shown in Fig. 4.

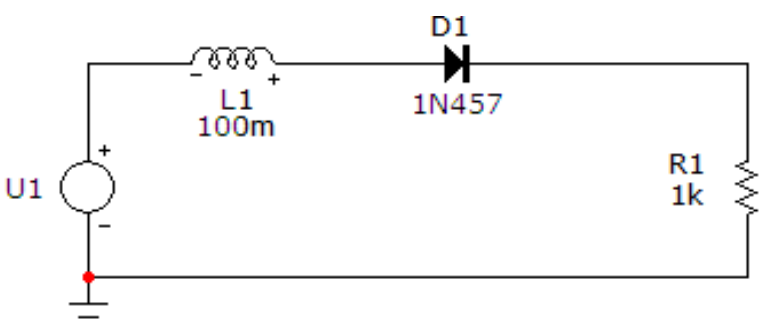

Figure 4. Model of chaotic oscillations' generator

Let us simulate the dependence between the output and input voltage, i.e. in MicroCap environment we obtain $u_{2}(t)=\psi\left(u_{1}(t)\right)$ function for different values of output voltage frequency $f$ with circuit parameters $L 1=100 \mathrm{mH}, R 1=1 \mathrm{kOhm}$ and diode type $1 \mathrm{~N} 457$. Please note that $u_{2}(t)=R i(t)$.

The diagrams of this dependency are shown in Figures 5-7. 


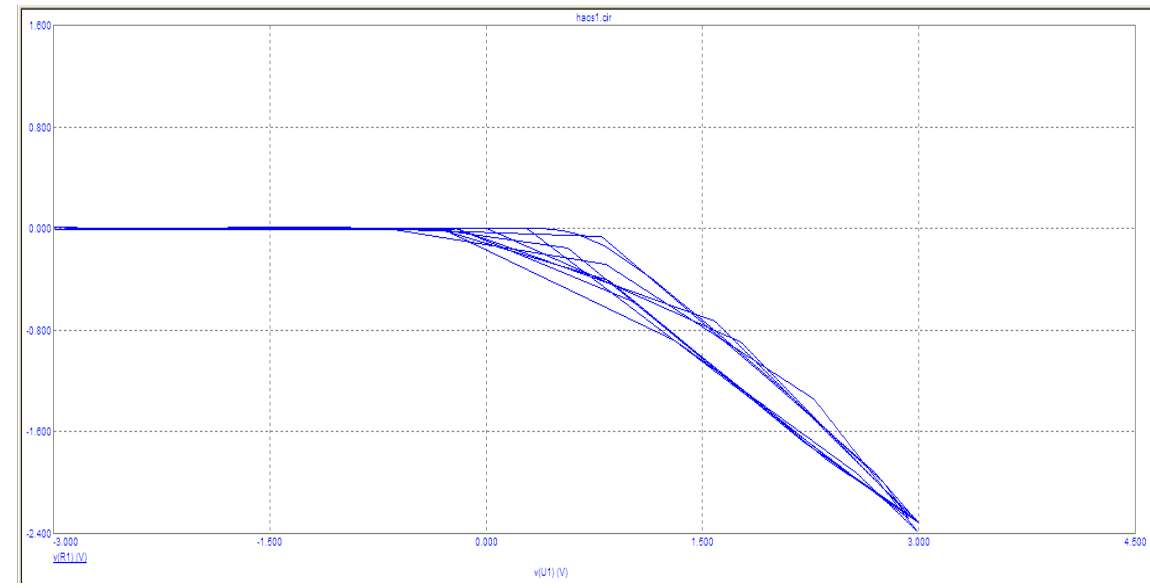

Figure 5. Diagram of function $u_{2}(t)=\psi\left(u_{1}(t)\right)$ at $100 \mathrm{~Hz}$ frequency

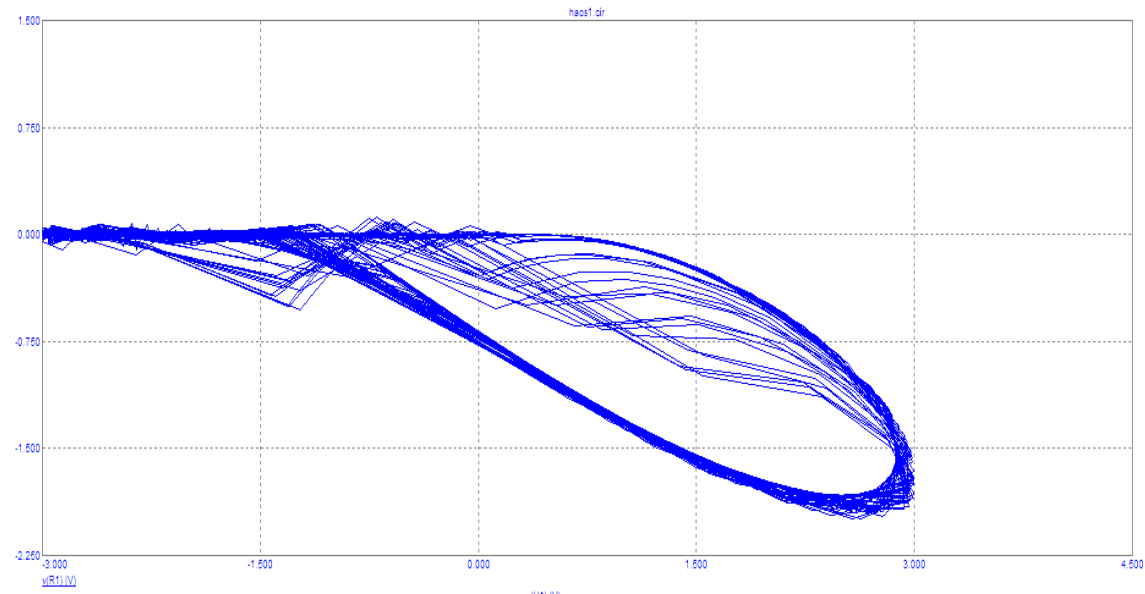

Figure 6. Diagram of function $u_{2}(t)=\psi\left(u_{1}(t)\right)$ at $1 \mathrm{kHz}$ frequency

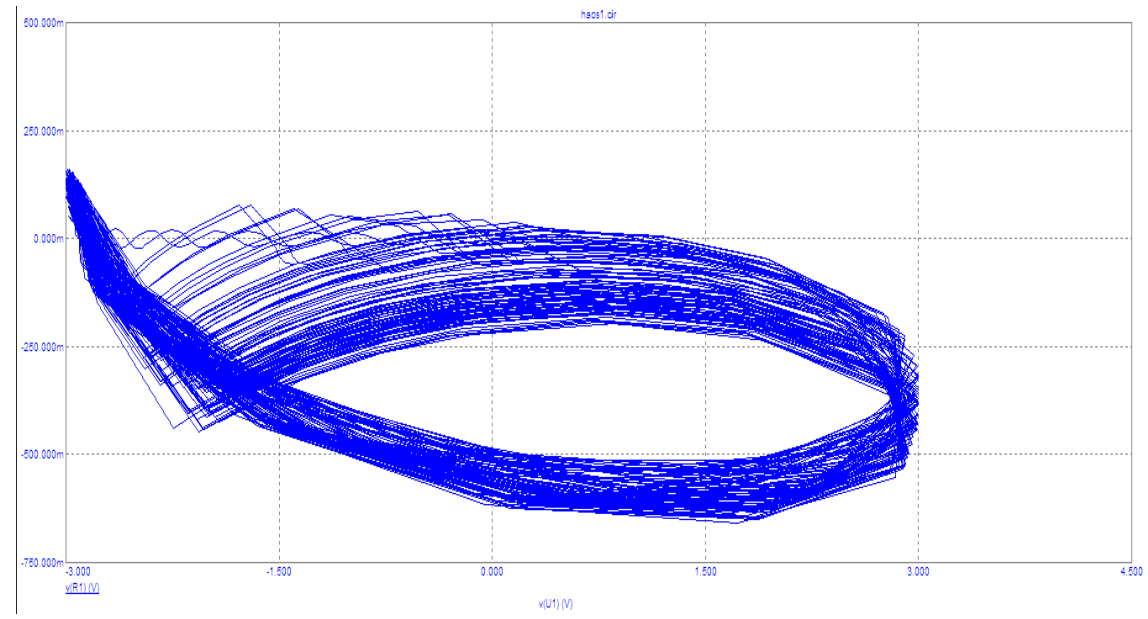

Figure 7. Diagram of function $u_{2}(t)=\psi\left(u_{1}(t)\right)$ at $10 \mathrm{kHz}$ frequency

It follows from diagram (Fig. 5) that, with the input voltage frequency of $100 \mathrm{~Hz}$, the circuit's transient process almost fades, and function $u_{2}(t)=\psi\left(u_{1}(t)\right)$ may be deemed deterministic.

With the input voltage frequency of $1 \mathrm{kHz}$ (Fig. 6), the circuit's transient process stops fading, and function $u_{2}(t)=\psi\left(u_{1}(t)\right)$ behaves in a chaotic manner. At the same time, the amplitude of chaotic oscillations is insignificant. 
Much better result was obtained with the frequency of $10 \mathrm{kHz}$ (Fig. 7), where the amplitude of chaotic oscillations is already significant.

Simulated in the paper were numerous options of circuits of chaotic oscillations' generator with various types of diodes and circuit parameters' values.

At first, simulations were made for generator operation modes with widespread diode types and equal circuit parameters $(L 1=100 \mathrm{mH}, R 1=1 \mathrm{kOhm})$ with recommended generator frequencies determined, under which the amplitude of chaotic oscillations is significant (Fig. 7). Simulation results are summarized in Table 1.

$\mathrm{T}$ a b 1 e 1

Dependence between the generator's recommended frequency and diode types

\begin{tabular}{|c|c|c|c|c|c|c|}
\hline Diode types & $\begin{array}{c}\text { 1N456- } \\
\text { 1N486 }\end{array}$ & $\begin{array}{c}\text { 1N625 - } \\
\text { 1N629 }\end{array}$ & $\begin{array}{c}\text { 1N658 - } \\
1 \mathrm{~N} 661\end{array}$ & $\begin{array}{c}\text { 1N746- } \\
1 \mathrm{~N} 749\end{array}$ & $\begin{array}{c}\text { 1N750- } \\
1 \mathrm{~N} 754\end{array}$ & $\begin{array}{c}\text { 1N755- } \\
1 \mathrm{~N} 759\end{array}$ \\
\hline Recommended frequency, $\mathrm{kHz}$ & 10 & 25 & 140 & 100 & 120 & 150 \\
\hline
\end{tabular}

It follows from Table 1 that, with equal circuit parameters, significant amplitude of chaotic oscillations may be reached at the lowest frequency of $10 \mathrm{kHz}$ for diode types 1N456 - 1N486 only.

Hereinafter, these diodes and this frequency underwent studies, during which determined were the ranges of the generator's optimal parameters that ensure an acceptable amplitude of chaotic oscillations. Study results are summarized in Table 2 .

T a b l e 2

\section{Optimal generator parameters}

\begin{tabular}{|l|c|c|c|}
\hline Inductance L1, $\mathrm{mH}$ & $10-100$ & $150-300$ & $350-500$ \\
\hline Resistor R1, kOhm & $0,01-0,4$ & $0,6-2$ & $2-4$ \\
\hline
\end{tabular}

\section{Conclusions}

1. This is a non-linear RL-diode electric circuit of sinusoid current, where an unfading transient process takes place, which, under given relationship between the input voltage frequency and circuit parameters may be deemed having a chaotic nature.

2. The transition from a deterministic process to a chaotic one takes place gradually rather than in a leap, that is why chaotic oscillations' generators require a significant amplitude (for a number of technical purposes, the amplitude of a chaotic component must exceed a deterministic one).

3. When designing such generators, it is advisable to use diodes of 1N456 - 1N486 types, since they ensure the lowest frequency (about $10 \mathrm{kHz}$ ), at which acceptable amplitude of chaotic oscillations is present.

\section{References}

1 Belik M. Usage of data acquisition device NI PCI-6221 for power engineering applications // Proceedings of the 201819 th International Scientific Conferenceon Electric Power Engineering (EPE). — Piscataway: IEEE, 2018. — P. $410-414$.

2 Belik M. Automated Data Acquisition For Electrical Power Engineering // Proceedings of the 14th International Scientific Conference EEE «Energy-Ecology-Economy 2018», 2018. — P. 124-128.

3 Kolpakova L.V. Chaotic-oscillator measuring devices / L.V.Kolpakova // Measuring and computing equipment in technological processes, 2011. - No. 2. P. - 101-104.

4 Kucheruk V. Generator oscylacji chaotycznych o układzie RL-dioda jako przetwornik rezystancja-napięcie / V. Kucheruk, Z.L. Warsza, V. Sevastyanow, W. Mankowska // Przegląd elektrotechniczny. — ISSN 0033-2097. — R. 89 NR 10/2013.

5 Alam J. Chasing Chaos with an RL-Diode Circuit / J. Alam, S. Anwar LUMS School of Science and Engineering. - 2010. - March 24.

6 Azzonz A. Orbitsofthe RL-Diode / A. Azzonz, M. Hasler // Circuits and Systems. — 1990. — No. 11. — Vol. 37. P. $1330-1338$.

7 Volodymyr Kucheruk. Deterministic chaos in RL-diode circuits and its application in metrology / Volodymyr Kucheruk // Proc. SPIE 10031, Photonics Applicationsin Astronomy, Communications, Industry, and High-Energy Physics Experiments. 2016. - No. 9.

8 Уве Хэндфорд. Аналоговая электроника. Основы, расчет, моделирование. - М.: Техносфера, 2008. — 472 с. 
В.В. Кухарчук, В.Ю.Кучерук, С.Ш. Кацыв, В.Ф. Граняк, Д.Ж. Карабекова, А.К. Хасенов

\title{
Синусоидалды токтың сызықты емес диодэлектрлік тізбегінде «детерминирленген хаос» құбылысының пайда болу шарттары
}

\begin{abstract}
Мақалада синусоидалды токтың сызықты емес RL-диодты электр тізбегіндегі «детерминирленген хаос» құбылысы зерттелді. Диод алмастыру схемасымен берілген, ол жалпы жағдайда сызықты емес резистор және барьерлік және диффузиялық - екісызықты емес сыйымдылықты қамтиды. Ток жиілігінің және тізбек параметрлерінің белгілі бір арақатынасы кезінде кіріс кернеуінің тербеліс кезеңінде өтпелі процестің аяқталуы іске аспайды. Бұл жағдайда әрбір кезеңнің басында сыйымдылықтарда қалдық кернеу болады, яғни өтпелі процестің әрбір жаңа циклінің нөлдік емес бастапқы жағдайлары бар. Әр кезеңдегі қалдық кернеу әртүрлі, сондықтан әр кезеңдегі тізбектегі ток та басқа. Осылайша, бұл жағдайда параметрлері хаостық сипатта болатын өшпейтін өтпелі процесс болады. «Детерминирленген хаос» құбылысын модельдеу MicroСар схемотехникалық модельдеу бағдарламасының ортасында жүргізілді. Диодтың әрбір түрі үшін модельдеу кезінде F, R, L (жиілік, жүктеме кедергісі, индуктивтілік) тізбектерінің көптеген параметрлері екі ішкі жиынға бөлінді - кіріс кернеуінің тербеліс кезеңінде өтпелі процесс аяқталатын ішкі жинақта (яғни сыйымдылықтардағы қалдық кернеу іс жүзінде нөлдік болып табылады), ал тізбектің жұмыс режимі детерминирленген деп санауға болады және ішкі жинаққа ол үшін өтпелі процесс кіріс кернеуінің тербеліс кезеңінде өшпейді (яғни сыйымдылықтардағы қалдық кернеу нөлден айтарлықтай өзгеше) және тізбектің жұмыс режимін хаостық деп санауға болады. Осылайша, хаостық тербеліс генераторларын құрастыру үшін тізбек параметрлерінің ұсынылған жиынтығы анықталды.
\end{abstract}

Кілт сөздер: детерминирленген хаос, барьерлік сыйымдылық, диффузиялық сыйымдылық, қалдық кернеу, бастапқы шарттар, тербеліс генераторы.

\author{
В.В. Кухарчук, В.Ю. Кучерук, С.Ш. Кацыв, \\ В.Ф. Граняк, Д.Ж. Карабекова, А.К. Хасенов
}

\section{Условия возникновения явления «детерминированный хаос» в нелинейной диодэлектрической цепи синусоидального тока}

\begin{abstract}
B статье исследовалось явление «детерминированный хаос» в нелинейной RL-диодной электрической цепи синусоидального тока. Диод представлен схемой замещения, которая в общем случае включает в себя нелинейный резистор и две нелинейные ёмкости - барьерную и диффузионную. При определенных соотношениях частоты тока и параметров цепи переходный процесс за период колебаний входного напряжения не успевает закончиться. В этом случае в начале каждого периода на ёмкостях присутствует остаточное напряжение, то есть каждый новый цикл переходного процесса имеет ненулевые начальные условия. Отметим, что остаточное напряжение в каждом периоде разное, поэтому ток в цепи в каждом периоде также разный. Таким образом, в этом случае происходит незатухающий переходный процесс, параметры которого носят хаотический характер. Моделирование явления «детерминированный хаос» проводилось в среде программы схемотехнического моделирования MicroCap. Bo время моделирования для каждого типа диода множество параметров цепи $\mathrm{f}, \mathrm{R}, \mathrm{L}$ (частота, сопротивление нагрузки, индуктивность) разделялось на два подмножества - на подмножество, для которого переходный процесс за период колебаний входного напряжения успевает закончиться (т.е. остаточное напряжение на ёмкостях является практически нулевым), а режим работы цепи можно считать детерминированным, и на подмножество, для которого переходный процесс за период колебаний входного напряжения не затухает (т.е. остаточное напряжение на ёмкостях существенно отличается от нуля) и режим работы цепи можно считать хаотическим. Таким образом, были определены рекомендованные совокупности параметров цепи для конструирования генераторов хаотических колебаний.
\end{abstract}

Ключевые слова: детерминированный хаос, барьерная емкость, диффузионная емкость, остаточные напряжения, начальные условия, генератор колебаний.

\section{References}

1 Belik, M. (2018). Usage of data acquisition device NI PCI-6221 for power engineering applications. Proceedings of the 2018 19th International Scientific Conferenceon Electric Power Engineering (EPE). (pp. 410-414). Piscataway: IEEE.

2 Belik, M. (2018). Automated Data Acquisition For Electrical Power Engineering. Proceedings of the 14th International Scientific Conference EEE «Energy-Ecology-Economy. (pp. 124-128). 
3 Kolpakova, L.V. (2011). Chaotic-oscillator measuring devices. Measuring and computing equipment in technological processes, No. 2, 101-104.

4 Kucheruk, V., Warsza, Z.L., Sevastyanow, V., \& Mankowska, W. (2013). Generator oscylacji chaotycznych o układzie RLdioda jako przetwornik rezystancja-napięcie. Przegląd elektrotechniczny, ISSN 0033-2097, R. 89 NR 10.

5 Alam, J.L., \& Anwar, S. (2010). Chasing Chaos with an RL-Diode Circuit. LUMS School of Science and Engineering.

6 Azzonz, A., \& Hasler, M. (1990). Orbitsofthe RL-Diode. Circuits and Systems, Vol. 37, No. 11, 1330-1338.

7 Volodymyr, Kucheruk, et al., (2016). Deterministic chaos in RL-diode circuits and its application in metrology. Proc. SPIE 10031, Photonics Applicationsin Astronomy, Communications, Industry, and High-Energy Physics Experiments, No. 9.

8 Uve, Naundford (2008). Analogovaia elektronika. Osnovy, raschet, modelirovanie [Analog electronics. Basics, calculation, modeling]. Moscow: Technosfera [in Russian]. 